\title{
Formulation of Internal Marketing Strategy to Improve Nurses' Work Engagement
}

\author{
Om Hashem Gomaa Ragab ${ }^{1} \&$ Nadia Mohamed Ali Saleh ${ }^{2}$ \\ 1. Lecturer of Nursing Administration, Faculty of Nursing, Sohag University, Egypt \\ 2. Assist. Prof. of Nursing Administration, Faculty of Nursing, Sohag University, Egypt
}

\begin{abstract}
Human resource as the first market of any organization needs to be motivated, educated and maintained in organizations at all costs to be globally competitive. Internal marketing is an effective strategy to follow for increasing nurses' work engagement. Aim: This study aims to: formulate of internal marketing strategy to improve nurses' work engagement. Research design: A correlational descriptive research design used to carry out this study. Setting: This study was conducted at Sohag University Hospital. Sample: The study sample composed of 148 staff nurses were randomly selected from different units and departments. Tools: three tools used: the $1^{\text {st }}$ consisted of personal characteristics and a question "what are your suggestions to increase nurses work engagement?" the $2^{\text {nd }}$ is Utrecht Work Engagement Scale-9 and the $3^{\text {rd }}$ is internal marketing questionnaire.Results: most of the sample was $85.1 \%$ females and $81.8 \%$ had diploma of technical institute of nursing, were $64.9 \%$ married, $33.1 \%$ have $3-5$ years of experience and $58.1 \%$ aged $25-<35$. Internal marketing and also nurses work engagement was low the mean and Std. deviation was $76.36 \pm 26.91$ and $26.78 \pm 16.81$ respectively. Conclusion There was highly statistical significance difference between low internal marketing in relation to low nurses work engagement. Recommendations: the hospital should adopt the internal marketing strategy to improve nurses' work engagement. Nurses' suggestions for work engagement should be considered. More research in nursing internal marketing should be conducted.
\end{abstract}

\section{Keywords: Internal Marketing, Nurses Work Engagement \& Strategy.}

\section{Introduction}

Human resource as the first market of any organization, they need to be motivated, educated and maintained in organizations at all costs to be globally competitive. Internal marketing is a means of involving employees at all levels in effective marketing programs and enabling them to understand their role within the processes. Internal marketing program consists of training and development, effective internal communication, and integrated schemes designed to enhance understanding of the overall marketing orientation within the organizations. Employees that understand their organizations vision, mission, and values produce more and represent the organization more effectively to the markets. Having a sound internal marketing strategy is more important than external marketing strategy (Shazia, 2017).

Internal marketing as a management strategy and philosophy influencing employees' attitudes and behavior through employees' selection, training, motivations, empowerment, retaining and development which all contributes significantly in improving the quality. Since employees of services organizations play an important role in delivering high quality services to external customers; therefore it is necessary to be acknowledgeable and skilled to handle and manage internal relationship, which enables them to provide high quality services to customers (Azzam, 2016).
Organizations should be capable of first selling the job to its employees prior to selling the service to the clients. Successful internal marketing depends on the acceptance of the concept by top management down to the staff. The effective implementation of internal marketing is expected to result in positive employee attitudes towards their tasks, organizational commitment and job satisfaction (Ismail \& Sheriff 2016).

Nurse work engagement, is a positive work-related state of mind that is characterized by feelings of vigour, dedication and absorption. Vigour is the high level of energy and mental resilience while working, along with a willingness to invest efforts in work and persistence when facing with difficulties. Dedication refers to being deeply involved in one's work with a sense of significance, enthusiasm, inspiration and challenge. Absorption is characterized by a thorough interest and immersion in work, so that the sense of time is lost (Wan et al., 2018).

Work engagement requires favorable conditions in the work environment such as favorable personal conditions and psychological safety as well as job resources including organizational, supervisory and coworker support, have motivational potential and should enhance employees' feelings of vigor, dedication, and absorption. Engaged employees provide high level of job performance due to: experience of positive emotions, 
have more physical resources making them healthier, they able to create and mobilize their own resources, and also they can transfer their engagement to their peers (Sonnentag, 2017, Nasurdin, et al., 2018).

Working in hospitals expose nurses to challenging physical and psychological work demands so considerations should be given for them to be more engaged in work and for providing high quality care (Swigera, et al., 2017). Work engagement positively affected by organizational trust, person-organization fit, job satisfaction and job reward that improves quality of care for patients, productivity and a positive attitude toward change (Ahmed, et al., 2016, Sulaiman \& Zahoni, 2016, Edwards-Dandridge, 2019) Work engagement was negatively associated with work burnout, servant leadership, high workload and depressive symptoms. Moreover work engagement, positively associated with high life satisfaction, increased mental health and recovery (Upadyaya, et al., 2016) Work Engagement is affected by nurses' self-confidence and commitment to the nursing job (Hontake \& Ariyoshi, 2018).

So the current state of internal marketing and work engagement should be measured to enable the formulation of internal marketing strategy to improve nurses work engagement.

\section{Significance of the study}

Recently the trend of quality and accreditation of higher education stresses the production of research articles that serves the community. From the previous point of views, the ideation of the current study comes out, includes a strategy formulation as a service based on extensive scientific research will be provided to nursing management, which will help them in the administrative role. The strategy formulated in Arabic, the native language of nursing management, for application at Sohag University Hospital so it will be more effective and fitting the purpose it prepared for. It prepared also to reduce the gap between academician and professional nursing. Communication with a number of nurses at Sohag University Hospital revealed that they have a low sense of engagement. The researchers thought that nurses' engagement will be improved if the internal marketing in the hospital improved. So that will support Egypt 2030 strategy.

Aim of the study

This study aimed to: formulate of internal marketing strategy to improve nurses' work engagement.

Research hypothesis

1. There is low level of internal marketing directed from the hospital to nurses.

2. There is low level of nurses' work engagement in Sohag University Hospital.
3. There is a positive relation between internal marketing and nurses' work engagement

\section{Subject \& Method \\ Technical design \\ Research design}

A correlational descriptive research design used to carry out this study.

Setting: This study was conducted at Sohag University Hospital.

Sample

The study sample composed of 148 staff nurses. Epi Info program version 7.2.3.1, used to detect the sample size at confidence level $90 \%$ and confidence limits 5\%. Nurses were randomly selected from different units and departments.

Tools of the study: It was consisted of three tools classified as follow:

First tool: it consisted of personal characteristics, included items related to gender, age, social status, qualification and years of experience. To benefit from nurses' opinion towards nurses work engagement issue the following open question was included: what are your suggestions to increase nurses work engagement? This tool had been developed by the researchers.

Second tool: The 2nd part is the 9 items Utrecht Work Engagement Scale-9 (UWES-9) developed by Schaufeli \& Bakker (2003) and adopted in this study. UWES-9 composed of 3 sub-concepts of "vigor", "dedication", and "absorption". Each of the 3 sub-scales consists of three items. The tool is a 7 points Likert scale: 0 never, 1 almost never/a few times a year or less, 2 rarely/once a month or less, 3 sometimes/a few times a month, 4 often/once a week, 5 very often/a few times a week and 6 always/every day. The higher score on the UWES-9 indicates more positive the attitude towards work. Reliability measured using Cronbach's Alpha test was 0.93.

Third tool: internal marketing questionnaire adapted from Ismail \& Sheriff (2015). The tool encompasses 28 items distributed as the following: vision 2 items, development 8 items, rewards 5 items, empowerment 7 items and internal communication 6 items. The tool is based on 5 points Likert scale, started from 1 strongly disagree to 5 strongly agree. Reliability measured using Cronbach's Alpha test it was 0.97.

Scoring system: The study sample result less than $60 \%$ considered having low level, results of $60 \%$ to less than $80 \%$ perceived as moderate while $80 \%$ and more considered high.

Administrative Design

An official permission was obtained from the nurse director, director of the Sohag University Hospital and the dean of Faculty of Medicine Sohag University. 
Operational Design

This design explains the steps of actual implementation of the study, including preparatory phase, the pilot, and the field work.

\section{Preparatory phase}

This phase started from February 2018 to August 2019 which included reviewing the available literature concerning to the study topic, prepare, translate the tools of data collection and drawing the framework for internal marketing strategy to improve nurses' work engagement. The draft of the questionnaires were reviewed for face validity by taking experts opinions through a jury comprised from 5 experts (three Professors from Nursing Administration Department and two Professors from Community Health Department) from Faculties of Nursing, Cairo and Ain Shams universities, to test comprehension of study tools.

\section{Pilot study}

It was done to explore any obstacles or problems that may be encountered during data collection phase. It helps also in estimating time needed to fill the questionnaire form. It was carried out on 20 nurses; the total period for collection of data in the pilot study takes about 6 days. The participants chosen for the pilot study were included in the total study sample.

Reliability was measured using Cronbach's Alpha Coefficients methods to ensure internal consistency and its result revealed that all statements of study questionnaire $\alpha$ were $>0.89$ for internal marketing questionnaire and > 0.87 for Utrecht Work Engagement Scale-9.

\section{Fieldwork}

Data collected regarding nurses' work engagement and internal marketing during September 2019. Strategy formulated from October to December 2019 in the light of analyzed data and reviewed literature.

\section{Strategy booklet content includes}

- Introduction (based on the introduction of the current research).

- The current position of internal marketing and nurses' engagement at Sohag University hospital (translated from the current research results).

- Aim of the strategy (improvement of internal marketing to improve nurses' work engagement).

- Strategic objectives (5) as following

- Formulating a clear vision that the nursing staff believes in.

- Continuously developing the skills and knowledge of the nursing staff to fulfill their roles while providing all the necessary resources for training and development.

o Preparing a mechanism to reward and motivate who excellent doing at work.

○ Empowerment of nurses is one of hospital work policies.
- Encourage internal communication with nursing in all directions.

- The strategy main items include "vision, development, reward, empowerment and internal communication" (each one of these main items is based on one of the previously mentioned strategic objectives divided in to: number of tactical objectives, related activities, time framework for these activities, and finally the expected outcomes).

- Methods of evaluation.

- The correspondence of the strategy with Egypt 2030 strategy.

- References

To protect the copy right of results after publishing the current research article the strategy booklet will be introduced to the Nurse Director, Director of Sohag University Hospital, Dean of Faculty of Medicine Sohag University and President of Sohag University to be reviewed and approved as a preceding step for implementation by the hospital.

\section{Ethical considerations}

Oral agreement was obtained from all participants after informing them about their rights to participate, refuse, or withdraw at any time. Total confidentiality of the obtained data was ensured.

\section{Statistical Analysis}

Data entry and statistical analysis were done using SPSS version 16.0 statistical software package. The collected data tabulated and presented in the form of frequencies, percentages, means and standard deviations, Chi-square test and regression coefficient test. Test of significance classified as: insignificant $\mathrm{P}$ $\geq 0.05$; significant $\mathrm{P}<0.05$ and highly significant $\mathrm{P}<0.01$. 


\section{Results}

Table (1): Frequencies distribution of nurses personal characteristics $(n=148)$.

\begin{tabular}{|c|c|c|}
\hline Personal characteristics & No & $\%$ \\
\hline \multicolumn{3}{|l|}{ Sex } \\
\hline - $\quad$ Male & 22 & 14.9 \\
\hline - $\quad$ Female & 126 & 85.1 \\
\hline \multicolumn{3}{|l|}{ Age } \\
\hline$-\quad$ Less than 25 & 38 & 25.7 \\
\hline$-\quad 25-<35$ & 86 & 58.1 \\
\hline$-\quad 35-<45$ & 20 & 13.5 \\
\hline - $\quad 45$ and more & 4 & 2.7 \\
\hline Mean \pm Std. Deviation & \multicolumn{2}{|c|}{$28.39 \pm 5.69$} \\
\hline \multicolumn{3}{|l|}{ Social status } \\
\hline - $\quad$ Single & 45 & 30.4 \\
\hline - $\quad$ Married & 96 & 64.9 \\
\hline - $\quad$ Divorced & 7 & 4.7 \\
\hline \multicolumn{3}{|l|}{ Qualification } \\
\hline - $\quad$ Bachelor & 3 & 2.0 \\
\hline - $\quad$ Diploma of technical institute of nursing & 121 & 81.8 \\
\hline - $\quad$ Diploma of secondary school of nursing 3 years & 24 & 16.2 \\
\hline \multicolumn{3}{|l|}{ Experience } \\
\hline - 2 years or less & 26 & 17.6 \\
\hline$-3-5$ & 49 & 33.1 \\
\hline$-6-10$ & 37 & 25.0 \\
\hline$-\quad 11-15$ & 21 & 14.2 \\
\hline - 16 or more & 15 & 10.1 \\
\hline
\end{tabular}

Table (2): Frequencies distribution and mean \pm Std. Deviation of internal marketing level $(n=148)$

\begin{tabular}{|l|c|c|c|c|c|c|c|}
\hline \multirow{2}{*}{\multicolumn{1}{|c|}{ Items }} & \multicolumn{2}{|c|}{ Low } & \multicolumn{2}{c|}{ Moderate } & \multicolumn{2}{c|}{ High } & \multirow{2}{*}{$\begin{array}{c}\text { Mean } \pm \text { Std. } \\
\text { Deviation }\end{array}$} \\
\cline { 2 - 7 } & No & $\mathbf{\%}$ & No & \% & No & \% & $5.39 \pm 2.27$ \\
\hline Vision & 77 & $\mathbf{5 2 . 0}$ & 21 & 14.2 & 50 & 33.8 & $22.24 \pm 8.37$ \\
\hline Development & 82 & $\mathbf{5 5 . 4}$ & 34 & 23.0 & 32 & 21.6 & $13.27 \pm 5.40$ \\
\hline Reward & 79 & $\mathbf{5 3 . 4}$ & 39 & 26.4 & 30 & 20.3 & $19.41 \pm 7.76$ \\
\hline Empowerment & 80 & $\mathbf{5 4 . 1}$ & 35 & 23.6 & 33 & 22.3 & $16.06 \pm 5.996$ \\
\hline Internal communication & 78 & $\mathbf{5 2 . 7}$ & 43 & 29.1 & 27 & 18.2 & $76.36 \pm 26.91$ \\
\hline Total internal marketing & 85 & $\mathbf{5 7 . 4}$ & 44 & 29.7 & 19 & 12.8 & \\
\hline
\end{tabular}

Table (3): Frequencies distribution and mean \pm Std. Deviation of nurses work engagement level $(n=148)$

\begin{tabular}{|l|c|c|c|c|c|c|c|}
\hline \multirow{2}{*}{ Items } & \multicolumn{2}{|c|}{ Low } & \multicolumn{2}{c|}{ Moderate } & \multicolumn{2}{c|}{ High } & \multirow{2}{*}{$\begin{array}{c}\text { Mean } \pm \text { Std. } \\
\text { Deviation }\end{array}$} \\
\cline { 2 - 8 } & No & $\mathbf{\%}$ & No & $\mathbf{\%}$ & No & \% & \\
\hline Vigor & 90 & $\mathbf{6 0 . 8}$ & 17 & 11.5 & 41 & 27.7 & $8.79 \pm 5.86$ \\
\hline Absorption & 97 & $\mathbf{6 5 . 5}$ & 20 & 13.5 & 31 & 20.9 & $8.36 \pm 5.61$ \\
\hline Dedication & 80 & $\mathbf{5 4 . 1}$ & 21 & 14.2 & 47 & 31.8 & $9.64 \pm 6.10$ \\
\hline Total of work engagement & 91 & $\mathbf{6 1 . 5}$ & 23 & 15.5 & 34 & 23.0 & $26.78 \pm 16.81$ \\
\hline
\end{tabular}


Table (4): Correlation between internal marketing and nurses' work engagement $(n=148)$.

\begin{tabular}{|c|c|c|c|c|c|c|c|c|c|}
\hline & & \multicolumn{6}{|c|}{ Internal Marketing } & \multirow{3}{*}{$\mathbf{X}^{2}$} & \multirow{3}{*}{ P - Value } \\
\hline \multirow{2}{*}{\multicolumn{2}{|c|}{ Items }} & \multicolumn{2}{|c|}{ Low } & \multicolumn{2}{|c|}{ Moderate } & \multicolumn{2}{|c|}{ High } & & \\
\hline & & No & $\%$ & No & $\%$ & No & $\%$ & & \\
\hline \multirow{3}{*}{$\begin{array}{l}\text { Work } \\
\text { Engagement }\end{array}$} & Low & 65 & 43.9 & 25 & 16.9 & 1 & 0.7 & \multirow{3}{*}{54.27} & \multirow{3}{*}{$0.000 * *$} \\
\hline & Moderate & 9 & 6.1 & 12 & 8.1 & 2 & 1.4 & & \\
\hline & High & 11 & 7.4 & 7 & 4.7 & 16 & 10.8 & & \\
\hline
\end{tabular}

** $P$. Value is highly significant at $P<0.01$

Table (5): Best fitting multiple linear regression models for internal marketing.

\begin{tabular}{|l|c|c|c|c|c|}
\hline \multirow{2}{*}{ Models } & \multicolumn{2}{|c|}{ Unstandardized Coefficients } & $\begin{array}{c}\text { Standardized } \\
\text { Coefficients }\end{array}$ & \multirow{2}{*}{ t } & \multirow{2}{*}{ Sig. } \\
\cline { 2 - 5 } & $\mathbf{B}$ & Std. Error & Beta & & \\
\hline (Constant) & 0.968 & 0.433 & --- & 2.237 & 0.027 \\
\hline Age & -0.009 & 0.014 & -0.068 & -0.594 & 0.553 \\
\hline Sex & -0.188 & 0.148 & -0.094 & -1.273 & 0.205 \\
\hline Social status & 0.220 & 0.107 & 0.166 & 2.051 & $0.042^{*}$ \\
\hline Qualification & 0.083 & 0.144 & 0.047 & 0.576 & 0.566 \\
\hline Experience & -0.031 & 0.069 & -0.052 & -0.444 & 0.658 \\
\hline Work Engagement & 0.432 & 0.065 & 0.508 & 6.697 & $0.000 * *$ \\
\hline
\end{tabular}

$* P$. Value is significant at $P<0.05 \quad * * P$. Value is highly significant at $P<0.01$

Table (6): Frequencies distribution of nurses suggestions to increase work engagement $(n=148)$

\begin{tabular}{|c|c|c|c|}
\hline \multicolumn{2}{|r|}{ Statement } & \multirow{2}{*}{$\begin{array}{l}\text { No } \\
21\end{array}$} & \multirow{2}{*}{$\frac{\%}{14.2}$} \\
\hline 1. & Listen to nursing destinations and their proposals. & & \\
\hline 2. & Respect for nursing and treat them well. & 13 & 8.8 \\
\hline 3. & Improving wages and increasing incentives. & 11 & 7.4 \\
\hline 4. & Improving work environment. & 11 & 7.4 \\
\hline 5. & Granting rewards to hardworking nurses. & 10 & 6.8 \\
\hline 6. & Conducting training courses to improve skills and knowledge. & 9 & 6.1 \\
\hline 7. & Communication between superiors and employees. & 8 & 5.4 \\
\hline 8. & Give nursing their rights & 8 & 5.4 \\
\hline 9. & Attention to the problems of nursing and solving them in a neutral manner, without violence and penalties. & 7 & 4.7 \\
\hline 10. & Justice and equality in dealing with and making decisions about nursing & 7 & 4.7 \\
\hline 11. & Reducing the number of shifts and hours of work. & 6 & 4.1 \\
\hline 12. & Consideration of their emergency and family circumstances. & 5 & 3.4 \\
\hline 13. & Provide a sufficient number of nurses. & 5 & 3.4 \\
\hline 14. & Changing the chief nursing and supervisors / choosing good managers. & 4 & 2.7 \\
\hline 15. & Motivating employees morally. & 4 & 2.7 \\
\hline 16. & Providing the necessary tools and equipment to provide the necessary care. & 4 & 2.7 \\
\hline 17. & Educating the medical team about the importance of nursing. & 3 & 2.0 \\
\hline 18. & Improving the quality of nursing work. & 3 & 2.0 \\
\hline 19. & Educate nursing about their rights and duties. & 2 & 1.4 \\
\hline 20. & Make a plan to develop the nursing process based on an intellectual and informational development. & 2 & 1.4 \\
\hline 21. & Appreciate their effort at work. & 1 & 0.7 \\
\hline 22. & Change / transfer to another department. & 1 & 0.7 \\
\hline 23. & Changing the hospital's policies and regulations, and the main goal will be nursing comfort. & 1 & 0.7 \\
\hline
\end{tabular}




\begin{tabular}{|c|c|c|c|}
\hline & Statement & No & $\%$ \\
\hline 24. & Correct distribution of nursing team between the departments. & 1 & 0.7 \\
\hline 25. & Establish a morale affairs department in the hospital to raise the morale of employees. & 1 & 0.7 \\
\hline 26. & Fair distribution of nursing throughout the day. & 1 & 0.7 \\
\hline 27. & Freedom to choose days in the monthly schedule. & 1 & 0.7 \\
\hline 28. & Holding weekly meetings to discuss the problems facing nursing and to suggest solutions. & 1 & 0.7 \\
\hline 29. & Improve the relationship between supervision and nursing. & 1 & 0.7 \\
\hline 30. & Improving infection control procedures. & 1 & 0.7 \\
\hline 31. & Improving nursing vision. & 1 & 0.7 \\
\hline 32. & Looking at nursing qualifications, not just years of experience. & 1 & 0.7 \\
\hline 33. & Providing a separate nursing room with a bed and a chair to rest in free working hours. & 1 & 0.7 \\
\hline 34. & Reducing psychological pressure on nursing. & 1 & 0.7 \\
\hline 35. & Take trips to improve the psychology of nursing. & 1 & 0.7 \\
\hline 36. & The words written in the paper (the questionnaire) is the dreams of nursing. & 1 & 0.7 \\
\hline
\end{tabular}

Table (1): Revealed that, most of the study sample was females $(85.1 \%)$ and had diploma of technical institute of nursing $(81.8 \%)$. The highest percentage of them were married $(64.9 \%)$, have $3-5$ years of experience $(33.1 \%)$ and aged from $25-<35$ years old $(58.1 \%)$. The age mean and Std. deviation was $(28.39 \pm 5.69)$.

Table (2): Demonstrates that, about $(57.4 \%)$ of total internal marketing was low. The mean and Std. deviation was $76.36 \pm 26.91$.

Table (3): Clarified that, about $(61.5 \%)$ of total nurses work engagement was low. The mean and Std. deviation was $26.78 \pm 16.81$.

Table (4): Declares that, the highest percentage (43.9\%) was low internal marketing in relation to low nurses work engagement. There was highly statistical significance difference $\mathrm{X}^{2}=54.27 \& \mathrm{P}<0.01$.

Table (5): Shows that the best fitting multiple linear regression models for internal marketing was significant in relation to social status $\mathrm{T}$-test $=2.051$, $\mathrm{P}<0.01$ and highly significant difference in relation to work engagement $\mathrm{T}$-test $=6.697, \mathrm{P}<0.01$.

Table (6): Depicted that, the frequently repeated statement was "Listen to nursing destinations and their proposals" had $14.2 \%$, followed by "Respect for nursing and treat them well" $8.8 \%$, then "Improving wages and increasing incentives" and "Improving work environment" had 7.4\%.

\section{Discussion}

Marketing concentrates on relationships, and the manifestation of these relationships equates to brand equity. Customers invest in relationships with those they know and those they trust (Stevens, 2016). Work engagement is vital for improving productivity, safety and patient experience. Healthcare managers urgently need to focus upon strategies to measure, analyze and improve work engagement among the employees (Jeve, et al., 2015).
This study revealed that the sample mostly composed of married females had diploma of technical institute of nursing with $3-5$ years of experience and aged from 25 - 35 years old. The current result is supported by Edwards-Dandridge (2019) who studied work engagement, job satisfaction, and nurse turnover intention founded that the primary sample consisted of $93.5 \%$ females, mean and Std. Deviation for years of experience was $18.38 \pm 13.48$ and for age was $43.95 \pm 12.69$. Additionally Sohrabizadeh \& Sayfouri (2014) studied the antecedents and consequences of work engagement among nurses showed that participants aged between 22-28 years and they had an average of 9.25 \pm 7.21 years of experience in nursing. In the same line Wan et al., (2018) studied the effects of work environment and job characteristics on the turnover intention of experienced nurses on work engagement most of participants were females $(98.0 \%)$ with an average age of 36.35 (SD 7.83) worked more than 20 years were married (83.9\%), and held a Bachelor degree or higher (57.6\%). The reverse was in the Hontake \& Ariyoshi, (2018) research of relationship between work engagement and job satisfaction of nurses in psychiatric hospital clarified that nurses $(52.6 \%)$ were males. The mean age was $39.1(\mathrm{SD} \pm 9.3)$ and the average years of nursing experience was 15.4 years ( $\mathrm{SD} \pm 9.6)$.

The finding of current study stated that the mean score of internal marketing and its five sub scales items includes vision, development, reward, empowerment and internal communication was low than average. That implies the least attention and efforts of internal marketing directed from the Sohag University Hospital to nurses as internal customers. This supports the first study hypothesis. The finding is in the same line with Shaip (2014 - 2015) who stated that internal marketing practices not effectively applied in health organizations. The results of this 
study are contradicted with Shazia, (2017) who clarified that there was moderate level of internal marketing.

The current results indicated that the mean score of nurses work engagement and its sub items includes vigor, absorption and dedication was low than average. That reflected in the nurses' suggestions to increase nurses work engagement. This supports the second study hypothesis. The study results is consistent with Jeve, et al., (2015) study showed that work engagement level was average to below average within National Health Service employees. Vigor and dedication were significantly lower. Moreover Hontake \& Ariyoshi, (2018) said that the average score of the UWES-9 were between 2.0 and 3.7 that revealed low level of nurses work engagement. This finding is inconsistent with Edwards-Dandridge (2019) who showed that the nurses work engagement level was average. Also Radwan et al., (2018) study of organizational support and work engagement as perceived by head nurses at Mansoura University Hospital observed high level of work engagement.

That result revealed there was highly statistical significance difference between internal marketing in relation to nurses work engagement. Regression analysis showed that there was significant relation between internal marketing in relation to social status and highly significant relation with work engagement. So if more attention has been given for internal marketing that inevitable will improve nurses work engagement level. This supports the third study hypothesis. In the same instance Kutney-Lee, et al., (2017) demonstrates that nurses work engagement varied widely among hospitals in USA. Forty-two percent of nurses were classified as most engaged; $36 \%$ moderately engaged; $19 \%$ somewhat engaged and $3 \%$ were least engaged. In hospitals with greater levels of engagement, nurses were significantly less likely to report unfavorable job outcomes and poor ratings of quality and safety. Finally Wan et al., (2018) revealed that work environment was positively associated with higher nurses work engagement and lower turnover intention.

\section{Conclusion}

The study results concluded that: the sample mostly composed of married females had diploma of technical institute of nursing with $3-5$ years of experience and aged from $25-<35$ years old. The mean score of internal marketing and work engagement and its sub scales items were low than average. There was highly statistical significance difference between internal marketing in relation to nurses work engagement. Regression analysis clarified that there was significant relation between internal marketing with social status and highly significant relation with work engagement.

\section{Recommendations}

- The hospital management should adopt the internal marketing strategy to improve nurses' work engagement that formulated in Arabic booklet for them includes five main items "vision, development, reward, empowerment and internal communication".

- Nurses' suggestions to increase nurses work engagement should be considered by the hospital management.

- More research should be conducted in the internal marketing in nursing field.

\section{References}

1. Ahmed, U., Abdul Majid, A., \& Zin, M., (2016): Meaningful Work and Work Engagement: A Relationship Demanding Urgent Attention. International Journal of Academic Research in Business and Social Sciences, Vol. (6), No. (8), Pp. 116-122.

2. Azzam, Z., (2016): Internal Marketing as a Tool for Maintaining High Quality Services Provided By Services Firms a Case of Hospitality Industry in Jordan. International Journal of Economics, Commerce and Management, United Kingdom, Vol. (IV), Issue (4), Pp. 380393. http://ijecm.co.uk/ ISSN 23480386.

3. Edwards-Dandridge, Y., (2019): Work Engagement, Job Satisfaction, and Nurse Turnover Intention. Doctoral Study, College of Management and Technology, Walden University. https://scholarworks.waldenu.edu/dissertations.

4. Hontake, T., \& Ariyoshi, H., (2018): Relationship between Work Engagement and Job Satisfaction of Nurses in Psychiatric Hospital. International Journal of Nursing Science, Vol. (8), No. (2), Pp. 21-26.

5. Ismail, W., \& Sheriff, N., (2015): Validation of Measurement Model of Internal Marketing in Banking Sector in Yemen. International Academic Research Journal of Social Science, Vol. (1), No. (2), Pp. 131-138.

6. Ismail, W., \& Sheriff, N., (2016): Impact of Internal Marketing on Job Satisfaction among Bank Employees in Yemen. BE-ci 2016: 3rd International Conference on Business and Economics, Pp. 21 - 23. September, 2016. http://dx.doi.org/10.15405/epsbs.2016.11.02.19.

7. Jeve, Y., Oppenheimer, C., \& Konje, J., (2015): Employee engagement within the NHS: a cross-sectional study. International Journal of 
Health Policy and Management, Vol, (4), No. (2), Pp. 85-90.

8. Kutney-Lee, A., Germack, H., Hatfield, L., Kelly, S., Maguire, P., Dierkes, A., Guidice, M., \& Dr. Aiken, L., (2017): Nurse Engagement in Shared Governance and Patient and Nurse Outcomes. J Nurs Adm, Vol. (46) No. (11), Pp. 605-612.

9. Nasurdin, A., Ling, T., \& Khan, S., (2018): Linking social support, work engagement and job performance in nursing. International Journal of Business and Society, Vol. (19), No. (2), Pp. 363-386.

10. Swigera, P., Patricianb, P., Miltnerc, R., Rajud, D., Breckenridge-Sproate, S., \& Loanf, L., (2017): The Practice Environment Scale of the Nursing Work Index: An updated review and recommendations for use. International Journal of Nursing Studies, Vol. (74), Pp. 76-84.

11. Radwan, S., Abo Gad, R., \& Kassem, A., (2018): Organizational Support and Work Engagement as Perceived by Head Nurses at Mansoura University Hospital. International Journal of Novel Research in Healthcare and Nursing, Vol. (5), Issue (3), Pp. 14-24.

12. Schaufeli, W., \& Bakker, A., (2003): UWESUtrecht Work Engagement Scale: Test Manual. Unpublished Manuscript, Department of Psychology, Utrecht University, Utrecht.

13.Shazia, Q., (2017): Impact of Internal Marketing on Employee \& Consumer Satisfaction: A Study of Banking Organizations in Kashmir. Journal of Emerging Technologies and Innovative Research (JETIR), Vol. (4), Issue (12), Pp. 593-600.

14. Sohrabizadeh, S., \& Sayfouri, N., (2014): Antecedents and Consequences of Work Engagement Among Nurses. Iran Red Crescent Med J., Vol. (16) No. (11), e16351.

15.Sonnentag, S., (2017): A task-level perspective on work engagement: A new approach that helps to differentiate the concepts of engagement and burnout. Burnout Research, Vol. (5) No. (2017), Pp. 12-20.

16. Stevens, D., (2016): Practice Management for Healthcare Professionals. $1^{\text {st }}$ ed., Chapter 5: marketing for doctors and staff. Momentum Press, New York. USA. P.p. $41-76$.

17.Sulaiman, W., \& Zahoni, N., (2016): Validation of the Utrecht Work Engagement Scale (UWES) in the Malaysian Context. International Journal of Social Science and Humanity, Vol. (6), No. (9), Pp. 672-676.

18. Upadyaya, K., Vartiainen, M., \& SalmelaAro, K., (2016): From job demands and resources to work engagement, burnout, lifesatisfaction, depressive symptoms, and occupational health. Burnout Research, Vol. (3), Pp. 101-108.

19. Wan, Q., Li, Z., Zhou, W., \& Shang, S., (2018): Effects of work environment and job characteristics on the turnover intention of experienced nurses: The mediating role of work engagement; J Adv Nurs., Vol. (74) Pp. 13321341.

\section{Arabic references}

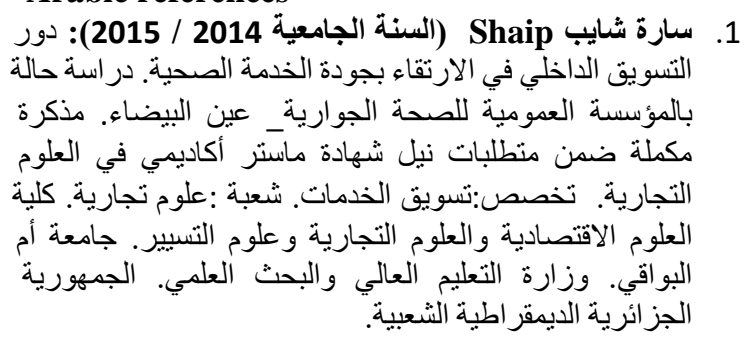

